\title{
Effect of dietary supplementation with arginine on haematological indices, serum chemistry, carcass yield, gut microflora and lymphoid organs of growing turkeys
}

by Oso, A.O., Williams, G.A., Oluwatosin, O.O., Bamgbose, A.O., Adebayo, A.O., Olowofeso, V., Pirgozliev, V., Adegbenjo, A.A., Osho, S.O., Alabi, J.O., Li, F., Liu, H., Yao, K. and Xin, W.

Copyright, Publisher and Additional Information: This is the author accepted manuscript. The final published version (version of record) is available online via Elsevier Please refer to any applicable terms of use of the publisher.

DOI: http://dx.doi.org/10.1016/i.livsci.2017.02.005

Harper Adams

University

Oso, A.O., Williams, G.A., Oluwatosin, O.O., Bamgbose, A.O., Adebayo, A.O., Olowofeso, V., Pirgozliev, V., Adegbenjo, A.A., Osho, S.O., Alabi, J.O., Li, F., Liu, H., Yao, K. and Xin, W. 2017. Effect of dietary supplementation with arginine on haematological indices, serum chemistry, carcass yield, gut microflora, and lymphoid organs of growing turkeys. Livestock Science, 198, pp. 58-64. 
1 Effect of dietary supplementation with arginine on haematological indices, serum chemistry, carcass yield, gut microflora, and lymphoid organs of growing turkeys

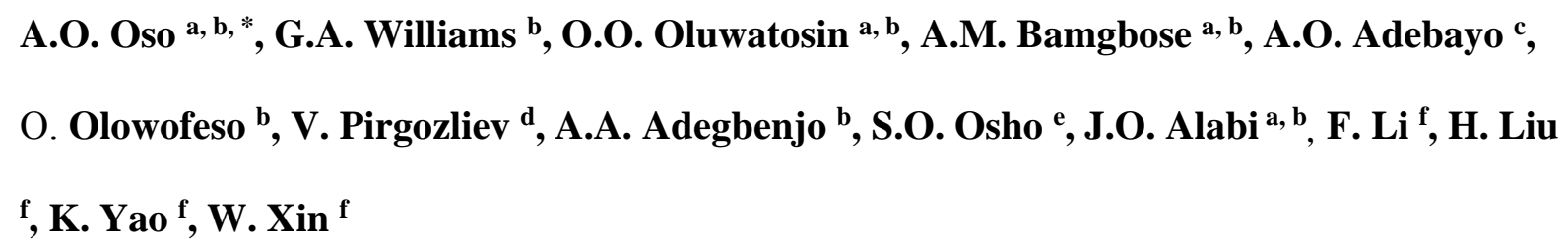

${ }^{a}$ World Bank Centre of Excellence in Agricultural Development and Sustainable Environment, Federal University of Agriculture, Abeokuta, PMB 2240, Nigeria.

${ }^{b}$ College of Animal Science and Livestock Production, Federal University of Agriculture, Abeokuta, PMB 2240, Nigeria.

${ }^{c}$ College of Veterinary Medicine, Federal University of Agriculture, Abeokuta, PMB 2240, Nigeria.

${ }^{d}$ Department of Animal Production, Welfare and Veterinary Sciences, Harper Adams University, Newport TF 10 8NB, United Kingdom.

${ }^{d}$ Department of Animal Sciences, Purdue University, West Lafayette, IN 47907-2054, United States.

${ }^{f}$ Key Laboratory for Agro-Ecological Processes of Subtropical Region, Institute of Subtropical Agriculture, The Chinese Academy of Sciences and Hunan Provincial Engineering Research Center for Healthy Livestock and Poultry Production, Changsha, 410125, China.

* Corresponding author. Tel.: +234 803725 2829; fax: +234 39244299. E-mail address: drosoann@yahoo.com (A.O. Oso). 


\section{A B S T R A C T}

A 8-wk feeding experiment was conducted to investigate the effect of dietary supplementation with Arg on haematological indices, serum chemistry, carcass yield, gut microflora, and lymphoid organ weights of growing turkeys. A total of one hundred and eighty 56-d-old male grower turkeys were weighed individually and randomly assigned to 1 of 3 dietary treatments with 6 replicate pens, and 10 turkeys per pen in a completely randomized design. Dietary treatments consisted of basal diets supplemented with $0,0.5$, and $1.0 \mathrm{~g} \mathrm{Arg} / \mathrm{kg}$. Haematological indices and serum chemistry were measured at 84 and $112 \mathrm{~d}$ of study. Carcass yield, relative weights of retail cuts, organ weights, and gut microflora were measured at d 112. Except eosinophil, no effect of Arg supplementation was obtained on haematological indices at $\mathrm{d} 84$. At $\mathrm{d} 112$, finisher turkeys fed the diet supplemented with $0.5 \mathrm{~g} \mathrm{Arg} / \mathrm{kg}$ had the greatest red blood cell (quadratic, $P<0.001$ ), lymphocyte (linear, $P=0.011$; quadratic, $P<0.001$ ), and basophil counts (quadratic, $P<0.001$ ). In grower turkeys at d 84 , total serum protein (quadratic, $P=$ 0.030 ), and serum globulin concentrations (quadratic, $P=0.043$ ) increased initially as Arg supplementation increased from 0 to $0.5 \mathrm{~g} / \mathrm{kg}$, but decreased with the $1.0 \mathrm{~g} \mathrm{Arg} / \mathrm{kg}$. Uric acid concentration and alanine aminotransferase activity reduced as Arg supplementation increased from 0 to $0.5 \mathrm{~g} / \mathrm{kg}$, but increased with the $1.0 \mathrm{~g} \mathrm{Arg} / \mathrm{kg}$ (quadratic, $P=0.002$ ). In finisher turkeys at $\mathrm{d} 112$, total serum protein (linear, $P=0.004$; quadratic, $P=0.002$ ), serum globulin (linear, $P=$ 0.008; quadratic, $P=0.030$ ), serum albumin (linear, $P=0.012$; quadratic, $P=0.040$ ), and triodosterine concentrations (linear, $P=0.025$; quadratic, $P=0.033$ ) increased with increasing Arg supplementation. At d 112, spleen weights increased linearly $(P=0.006)$, while thymus weights increased quadratically $(P=0.003)$ with increasing dietary Arg supplementation. 
Salmonella counts in the small intestinal content of turkeys at d 112 reduced quadratically as Arg supplementation increased from 0 to $1.0 \mathrm{~g} / \mathrm{kg}(P=0.029)$. In conclusion, Arg supplementation increased packed cell volume of finisher turkeys, improved serum chemistry of grower, and finisher turkeys as indicated by increased total serum protein, and reduced serum enzymes with appreciable improvement obtained when included at $0.5 \mathrm{~g} \mathrm{Arg} / \mathrm{kg}$. Arginine supplementation enhanced the relative weights of thymus, spleen, and reduced Salmonella counts in small intestine of turkeys.

Keywords: Carcass yield, Gut microflora, Heamatological indices, Lymphoid organs, Serum chemistry

\section{Introduction}

Arginine is a functional amino acid needed as building blocks of proteins and polypeptides, functions in the regulation of key metabolic pathways that are necessary for maintenance, growth, reproduction, and immunity (Liu et al., 2012; Wu, et al., 2012). Arginine acts as substrate for biosynthesis of several molecules such as protein, nitric oxide (NO), proline, ornithine, polyamines, glutamate, and glutamine (Khajali and Wideman, 2010). Arginine regulated the expression of fat metabolic genes in porcine adipose tissues and skeletal muscles (Tan et al., 2011), increased muscle gain, and reduced body fat mass in growing-finishing pigs (Tan et al., 2009). Arginine has also been shown to ameliorate intestinal abnormalities and attenuate growth depression in pigs fed mold-contaminated diets (Yin et al., 2014). The relevance of Arg in the nutrition of poultry has been reported in literature. Arginine improved the growth performance of broiler chickens (Chen et al., 2011), improved carcass traits, and breast meat yield of meat-type ducks (Wu et al., 2011). Reduced carcass yield, breast meat yield 
(Khajali et al., 2011), and leg muscle weight (Jiao et al., 2010) were also reported in broilers fed with Arg-deficient diets.

Arginine has been reported to improve the health status of humans and animals (Uni and Ferket 2003; Wu, 2009). Infected mice showed improved reproductive performance (Ren et al., 2012) and positive pregnancy outcomes (Ren et al., 2013) following dietary supplementation with Arg. Remarkable changes in serum profile of amino acids that alleviated damages caused by Dextran Sulphate Sodium Colitis were reported in mice following Arg supplementation (Ren et al., 2014). The white blood cell concentration and heterophil count in laying hens (Al-Hassani, 2011), as well as packed cell volume (PCV), red blood cell (RBC), and haemoglobin (Hb) concentrations of broiler chickens (Al-daraji and Salih, 2012) were influenced following dietary supplementation with Arg. Arginine plays a vital role in the development of lymphoid organs, which are crucial for effective immune system (Stechmiller et al., 2005). Dietary supplementation with Arg improved thymus functioning and spleen development (Bistrain, 2004). Relative weight of lymphoid organs reduced in chickens fed diet deficient in Arg when compared with chickens fed the Arg-supplemented diets (Kwak et al., 1999).

The achievement of improved gut health is dependent on intestinal environment and gut microflora, which protect the host from oral pathogens (Ziegler et al., 2003). The influence of nitric oxide (a metabolic molecule produced by Arg) on innate immunity (Ren et al., 2014) and the proliferation of intestinal pathogenic microbes (Allen, 1999; Li et al., 2007) has been reported in literatures. Nitric oxide (NO) played a vital role in the destruction of some pathogenic microbes by neutrophils and macrophages (Li et al., 2007). Daily oral administration of $500 \mathrm{mg}$ $\mathrm{Arg} / \mathrm{kg}$ alleviated unhealthy effects and negative impact of Eimeria tenella in chickens (Allen, 1999). Dietary inclusion of Arg improved the proliferation of intestinal intra-epithelial 
lymphocytes and increased its toxicity against infectious bursal disease virus in chickens (Tayade et al., 2006). This study investigated the effect of supplemental Arg on haematological indices, serum chemistry, carcass yield, gut microflora, and lymphoid organs of growing turkeys.

\section{Materials and methods}

\subsection{Management of turkeys}

This study was conducted at the turkey unit of the Teaching and Research Farms, University of Agriculture, Abeokuta, Nigeria during the late dry season. Experimental procedures complied with the guidelines of the Animal Care Committee of the Federal University of Agriculture (Abeokuta, Nigeria). A total of 200 one-day-old, male turkey poults obtained from a commercial hatchery (British United Turkeys; Obasanjo Farms Ltd, Ibadan, Nigeria) were reared together under a deep litter housing system for a 56-d pre-experimental period. Dried wood shavings were used as litter material. The pre-experimental period lasted for the pre-starter ( $\mathrm{d} 0$ to 28 ) and starter (d 28 to 56) phases of the turkeys. Brooding of turkeys was done for 0 to $28 \mathrm{~d}$ of age, while normal ambient temperature prevailed after the brooding period. Turkeys were fed with commercial maize-soybean meal based pre-starter (metabolizable energy $(\mathrm{ME})=11.79 \mathrm{MJ} / \mathrm{kg}$, crude protein $(\mathrm{CP})=278 \mathrm{~g} / \mathrm{kg}$, Met $=5.1 \mathrm{~g} / \mathrm{kg}$, and Lys $=16 \mathrm{~g} / \mathrm{kg})$ and starter diets $(\mathrm{ME}=12.13 \mathrm{MJ} / \mathrm{kg}, \mathrm{CP}=259 \mathrm{~g} / \mathrm{kg}$, Met $=4.6 \mathrm{~g} / \mathrm{kg}$, and Lys $=15 \mathrm{~g} / \mathrm{kg})$, which met the NRC (1994) nutritional requirements of the various age groups. During the pre-experimental period, feed and clean water were supplied ad libitum, while no mortality occurred. After the 56d pre-experimental period, the feeding study was initiated, which lasted for $8 \mathrm{wk}$.

\subsection{Dietary treatments and composition}



allotted to 1 of 3 treatments with 6 pens (dimension, $2.5 \times 1.8 \mathrm{~m}$ ) per treatment, and 10 turkeys per pen in a completely randomized design. A total of 18 similar floor pens were used in this

117 study. The pens were furnished with wood shavings as beddings. A maize-soybean meal diet (basal diet), which met the NRC (1994) nutritional requirement was formulated for grower (d 56 to 84 ), and finisher (d 84 to 112) phases of turkeys (Table 1). Two additional experimental diets were subsequently formulated for the grower and finisher phases by supplementing the basal diet with 0.5 , and $1 \mathrm{~g} \mathrm{Arg} / \mathrm{kg}$ (Shanghai TECH Chemical Industry, Shanghai, China). Turkeys had ad libitum access to feed and water. Feed samples were analyzed for dry matter (Method 934.01), crude fibre (Method 978.01), ether extract (Method 920.39), ash (Method 942.05), and crude protein $(\mathrm{N} \times 6.25$; Method 990.03) using standard methods of AOAC (2000). Amino acids contents of the feed samples were determined (Harper Adams University Laboratory, Newport, UK) using HPLC (SSNIFF Spezialdiäten GmbH, Soest, Germany) and following standard methods (European Commission, 1998).

\subsection{Measurement of haematological indices and serum chemistry}

\subsubsection{Blood sample collection}

At 84 and $112 \mathrm{~d}$ of study, blood sample ( $3 \mathrm{~mL}$ each) was collected from the brachial wing vein of one turkey per pen (selected at random) into vials containing ethylene diamine tetraacetate for the determination of haematological indices. Another set of blood was collected into plain bottles (without ethylene diamine tetra-acetate), centrifuged $\left(2,500 \times g\right.$ for $15 \min$ at $8^{\circ} \mathrm{C}$ ), and used for serum chemistry analysis.

\subsubsection{Haematological indices}


Hemoglobin concentration $(\mathrm{Hb})$ was estimated using the cyanmethaemoglobin method (Cannan, 1958). Packed cell volume (PCV), red blood cell (RBC), and white blood cell counts (WBC) were determined with Wintrobe haematocrit tube according to the method of Schalm et al. (1975). Differential leucocyte counts (heterophils, lymphocytes, basophils, eosinophils, monocytes) were carried out on blood smears stained with May-Grunwald-Giemsa stain and further calculated.

\subsubsection{Serum chemistry}

Total serum protein (Varley et al., 1980) and serum uric acid concentrations (Wootton, 1964) were measured according to standard procedures. Serum enzymes such as aspartate aminotransferase (AST) and alanine aminotransferase (ALT) were determined according to Bergmeyer (1983) with the aid of commercial kits (Roche COBAS testing Kits, Roche, Basel, Switzerland). Total thyroxine $\left(\mathrm{T}_{4}\right)$ concentration (Kozwich et al., 2000) and triodotyronine $\left(\mathrm{T}_{3}\right)$ (Kozdag et al., 2005) were measured according to standard procedures.

\subsection{Carcass yield}

At d 112, 1 turkey per pen whose weight is a representative of the average weight of turkeys in each pen was selected, slaughtered, defeathered, and eviscerated following standard commercial procedures (Jensen, 1984). The body weight and dressed weights, were measured, while the dressing percentage was calculated. Cut parts, which include head, neck, breast, back, thighs, drumsticks, and shanks, were weighed, and recorded as relative weights (percentage of body weight). The organs, which include kidney, lungs, gizzard, liver, heart, caecum, bursa, and spleen, were collected, weighed, and calculated as percentages of respective body weights

\subsection{Gut microflora}



sets of intestinal contents. Fresh digesta from the small intestine (from the distal end of the duodenum to the ileo-caecal junction) were collected and emptied into labeled sterile bottles.

161 Fresh cecal content collected from a pair of ceca of the selected turkey was also collected in different labeled sterile bottle. All samples collected were used for the estimation of gut microbiota according to the methods of Xia et al. (2004). One gram of sample was dispersed in a $9 \mathrm{~mL}$ phosphate-buffered saline solution with $0.5 \mathrm{~g} / \mathrm{L}$ of Cys. $\mathrm{HCl}$, and further diluted to a factor of $10^{-8}$. For the enumeration of bacteria, $0.1 \mathrm{~mL}$ of diluted sample was spread onto Petri dish containing selective media. The small intestinal and cecal content samples were incubated with Wilkins-Chalgren agar (Merck GmbH, Darmstadt, Germany) + novobiocin (8 mg/L) + colistin sulphate $(8 \mathrm{mg} / \mathrm{L})$ at $37^{\circ} \mathrm{C}$ for $72 \mathrm{~h}$ for estimation of clostridium counts, ES agar (Merck $\mathrm{GmbH}$, Darmstadt, Germany) at $37^{\circ} \mathrm{C}$ for $24 \mathrm{~h}$ for estimation of coliform counts, de Man Rogosa Sharpe agar (Merck KGaA, Foster City, California, United States) at $37^{\circ} \mathrm{C}$ for $72 \mathrm{~h}$ for estimation of lactobacilli count, and brilliant green agar (Merck Ltd, Mumbai, India) at $37^{\circ} \mathrm{C}$ for $24 \mathrm{~h}$ for estimation of salmonella count. Microbial counts were expressed as colony-forming units (cfu) of microorganism per gram of fresh sample.

\subsection{Statistical analysis}

Colony-forming units calculated per gram of sample obtained for gut microflora were transformed as $\log 10$ of viable bacteria per gram of fresh matter. Data obtained from this study was subjected to one-way analysis of variance as a completely randomized design. The pen was used as the experimental unit for the statistical analysis. The data were analyzed using the 
ANOVA procedure of SAS (1999). Linear and quadratic polynomial contrasts were applied to evaluate the effect of varying supplemental levels of Arg.

\section{Results}

\subsection{Haematological indices}

Table 2 shows the effect of Arg supplementation on haematological indices of grower and finisher turkeys measured at d 84 and 112, respectively. Except eosinophil, no effect of Arg supplementation was obtained on haematological indices measured at $d 84$. Dietary supplementation with $1 \mathrm{~g}$ Arg $/ \mathrm{kg}$ showed a linear reduction $(P=0.017)$ in eosinophil value.

In finisher turkeys at $112 \mathrm{~d}, \mathrm{PCV}$ increased (linear, $P=0.019$; quadratic, $P=0.017$ ) with Arg supplementation. Lymphocytes increased linearly and quadratically (linear, $P=0.011$; quadratic, $P<0.001)$, RBC and basophil counts increased quadratically $(P<0.001)$ initially as Arg supplementation increased from 0 to $0.5 \mathrm{~g} / \mathrm{kg}$, but decreased with the $1.0 \mathrm{~g} \mathrm{Arg} / \mathrm{kg}$. Heterophil (linear, $P=0.032$; quadratic, $P<0.001$ ), monocyte (linear, $P=0.019$; quadratic, $P<$ 0.001 ), and WBC counts (quadratic, $P=0.004$ ) reduced initially as Arg supplementation increased from 0 to $0.5 \mathrm{~g} / \mathrm{kg}$, but increased with the $1.0 \mathrm{~g} \mathrm{Arg} / \mathrm{kg}$.

\subsection{Serum chemistry}

The effect of Arg supplementation on serum chemistry of grower and finisher turkeys measured at 84 and $112 \mathrm{~d}$ of study is shown in Table 3. At d 84, total serum protein (quadratic, $P$ $=0.030$ ) and serum globulin concentrations (quadratic, $P=0.043$ ) increased initially as Arg supplementation increased from 0 to $0.5 \mathrm{~g} / \mathrm{kg}$, but decreased with the $1.0 \mathrm{~g} \mathrm{Arg} / \mathrm{kg}$. Uric acid concentration and ALT activity reduced quadratically $(\mathrm{P}=0.002)$ as Arg supplementation 
increased from 0 to $0.5 \mathrm{~g} / \mathrm{kg}$, but increased with the $1.0 \mathrm{~g} \mathrm{Arg} / \mathrm{kg}$. Similarly, ALP activity reduced linearly and quadratically with increasing Arg supplementation (linear and quadratic, $P$ $<0.001)$

At d 112, total serum protein (linear, $P=0.004$; quadratic, $P=0.002$ ), serum globulin (linear, $P=0.008$; quadratic, $P=0.030$ ), serum albumin (linear, $P=0.012$; quadratic, $P=$ 0.040 ), and $T_{3}$ concentrations (linear, $P=0.025$; quadratic, $P=0.033$ ) increased with increasing Arg supplementation. Alanine aminotransferase and AST concentrations reduced linearly and quadratically with increasing Arg supplementation (linear and quadratic, $P<0.001$ ). Serum uric acid concentration reduced linearly and quadratically as Arg supplementation increased from 0 to $0.5 \mathrm{~g} / \mathrm{kg}$, but increased with the $1.0 \mathrm{~g} \mathrm{Arg} / \mathrm{kg}$ (linear and quadratic, $P<0.002$ ).

\subsection{Carcass yield and lymphoid organs}

The effect of Arg supplementation on carcass yield and relative organ weights of finisher turkeys at $\mathrm{d} 112$ is shown in Table 4. Highest body weight (quadratic, $\mathrm{P}=0.040$ ), defeathered weight (quadratic, $\mathrm{P}=0.040$ ), and dressing percentage (linear, $\mathrm{P}=0.042$; quadratic, $\mathrm{P}=0.022$ ) were recorded with turkeys fed the diet supplemented with $1 \mathrm{~g} \mathrm{Arg} / \mathrm{kg}$. Dietary supplementation with Arg had no effect on the relative weights of retail cut parts. The spleen weights increased linearly $(P=0.006)$, while thymus weights increased quadratically $(P=0.003)$ with increasing dietary Arg supplementation. The relative weight of the heart reduced quadratically $(P<0.003)$ as Arg supplementation increased from 0 to $0.5 \mathrm{~g} / \mathrm{kg}$, but later increased with the $1.0 \mathrm{~g} \mathrm{Arg} / \mathrm{kg}$.

\subsection{Gut microflora}

Table 5 shows the effect of Arg supplementation on gut microflora of turkeys at $d$ 112. Clostridium and Coliform counts of the small intestinal content increased linearly, and 
quadratically $(P<0.001)$, while Salmonella counts reduced quadratically $(P=0.029)$ as Arg supplementation increased from 0 to $1.0 \mathrm{~g} / \mathrm{kg}$. Lactobacillus counts of the small intestinal content reduced quadratically as Arg supplementation increased from 0 to $0.5 \mathrm{~g} / \mathrm{kg}$, but showed a quadratic increase with the $1.0 \mathrm{~g} \operatorname{Arg} / \mathrm{kg}(P=0.002)$.

Cecal content of turkeys at $\mathrm{d} 112$ showed a quadratic increase in Lactobacillus counts as Arg supplementation increased from 0 to $1.0 \mathrm{~g} / \mathrm{kg}(P=0.030)$. Dietary supplementation with $A r g$ had no effect on cecal Clostridium, Coliform, and Salmonella counts

\section{Discussion}

\subsection{Haematological indices}

The findings of the present study which showed no effect of Arg on PCV, Hb, RBC, WBC, heterophil, lymphocyte, basophil, and monocyte counts of grower turkeys at d 94 suggested that Arg supplementation posed no adverse effect on the health status of growing turkeys. This corroborates the findings of Emadi et al. (2010) and Atakisi et al. (2009) who reported that Arg supplementation posed no adverse effect on health status but rather improved some blood traits of broilers. Al-Hassani, (2011) also reported no significant effect of Arg supplementation on lymphocyte, heterophil, basophil nor monocyte of laying hens.

A linear and quadratic increase in PCV of finisher turkeys at $112 \mathrm{~d}$ with Arg supplementation obtained in the current study implied improved protein intake and tissue synthesis. Reduced PCV in poultry birds have been linked with inhibition of protein synthesis, immune suppression, and anaemic condition (Denli et al., 2009). Quadratic increase in RBC of finisher turkeys at d 112 as Arg supplementation increased from 0 to $0.5 \mathrm{~g} / \mathrm{kg}$ implied higher oxygen carrying capacity of the blood and improved health status of finisher turkeys at $0.5 \mathrm{~g} \mathrm{Arg} / \mathrm{kg}$. The findings of this study 
agreed with Al-Daraji and Salih (2012) who reported that Arg supplementation improved erythrocyte count, PCV, and haemoglobin concentration of broiler chickens. The mechanism behind improved PCV and RBC concentrations obtained with Arg supplementation could be linked with the secretion of insulin-like growth factor (IGF) following supplemental Arg (Le Roith et al., 2001), which in turn fosters the proliferation, and differentiation of burst and colony forming units erythroid, myeloid progenitor, and peripheral blood cells (Deicher and Walter, 2005). The proliferation, differentiation, and maturation of RBC stimulated by Arg is as a result of erythropoietin, which is the hematopoietic growth factor produced by the kidney. This factor acts directly on certain RBC progenitors and precursors in the bone marrow (Westenfelder, 2002).

The linear reduction in WBC counts, linear and quadratic reduction in heterophil, and monocyte counts of finisher turkeys at d 112 as Arg supplementation increased from 0 to 0.5 $\mathrm{g} / \mathrm{kg}$ obtained in this study implied improved health status with finisher turkeys fed the diet supplemented with $0.5 \mathrm{~g} \mathrm{Arg} / \mathrm{kg}$. Elevated WBC counts have been recorded under diseased condition, infection or immune system disorder (Maroufyan et al., 2010). Heterophils have phagocytic action in the inflammatory response against infectious agents (Montalli, 1988) and are essential in fighting infection in poultry (Swaggerty et al., 2005). Reduced heterophil counts were also obtained in broiler chickens fed diets supplemented with Arg (Al-Daraji and Salih, 2012).

Linear and quadratic increase in lymphocyte counts of finisher turkeys at $\mathrm{d} 112$ obtained in the present study as Arg supplementation increased from 0 to $0.5 \mathrm{~g} / \mathrm{kg}$ could be related to the positive effect of Arg on thymus size which stimulates the production of lymphocytes by the thymus, and restores the production of thymic hormones to higher levels (Dean, 1999). This 
could be connected with the increased thymus weights obtained with turkeys fed diet supplemented with L-arg. The health status and lymphocyte counts of animals have been associated with the development and size of lymphoid organs. Chickens fed diet deficient in Arg has been reported to show reduced lymphocyte counts, poor thymus, and spleen development (Kwak et al., 1999).

\subsection{Serum chemistry}

The quadratic increase in total serum protein and serum globulin concentrations of grower turkeys as Arg supplementation increased from 0 to $0.5 \mathrm{~g} / \mathrm{kg}$, linear and quadratic increase in total serum protein, serum albumin, and globulin of finisher turkeys with increasing Arg supplementation suggested improved health status, and efficient dietary protein utilization following Arg supplementation. Reduced total serum protein concentration has been implicated as indications of low dietary protein utilisation (Schalm et al., 1975). The trend observed in the present study agreed with results of Emadi et al. (2011) who reported increased total serum protein and serum albumin following Arg supplementation. Increased serum protein concentration obtained following dietary supplementation with Arg could be due to the stimulating effect of Arg on pituitary and pancreatic hormones. Arginine has been reported to stimulate the release of pituitary and pancreatic hormones, including glucagon, and growth hormone which in turn increase protein synthesis (Davila et al., 1987).

The linear and quadratic increase in $T_{3}$ concentration of finisher turkeys at $d 112$ with increasing Arg supplementation obtained in the current study may be related to an increased metabolic rate, especially related to energy production, as well as improved growth, and development of the turkeys. Thyroid hormones $\left(\mathrm{T}_{3}\right.$ and $\left.\mathrm{T}_{4}\right)$ are involved in a wide range of 
metabolic activities influencing energy production, growth, and development. Klandorf et al. (1981) confirmed that $T_{3}$ was metabolically more active during energy production. Bobek et al. (1976) showed that $\mathrm{T}_{3}$ played far greater roles in bio-oxidation processes in cells, regulating oxygen consumption in growing chickens than $\mathrm{T}_{4}$. Linear and quadratic reduction in ALP concentration of grower turkeys at d 84, ALT, and reduction in AST concentrations of finisher turkeys at d 112 with increasing Arg supplementation in the present study indicated good health status, and lack of abnormalities in liver functioning. Serum enzyme concentrations were reported to exist at low concentration in a normal healthy animal but increased under stressful conditions, hepatotoxic situation, and inhibition of protein synthesis (Grunwaldt et al., 2005). Increased concentration of liver enzymes has been reported in situations of liver abnormalities, stress, and disease condition (Ewuola et al., 2008). Rosa et al. (2001) reported impaired carbohydrate, and lipid metabolism in animals with increased liver enzymes. The least serum uric acid obtained with grower and finisher turkeys fed the diet supplemented with $0.5 \mathrm{~g} \mathrm{Arg} / \mathrm{kg}$ showed indications of improved, efficient protein utilization, and reduced deamination following Arg supplementation in a dose-dependent manner. Oduguwa and Ogunmodede (1995) reported high serum uric acid concentrations due to inefficient protein utilization. High serum uric acid concentration has been reported to be typical of animals fed with nutritionally imbalanced dietary amino acids (Szabo et al., 2005).

\subsection{Carcass yield and lymphoid organs}

The role of Arg in protein synthesis, tissue accretion, and subsequently on carcass yield has been documented (Kwak et al., 1999; Kidd et al., 2001). Highest body weight, defeathered weight, and dressing percentage obtained in the current study with turkeys fed the diet 
supplemented with $1 \mathrm{~g} \mathrm{Arg} / \mathrm{kg}$ agreed with the study of Al-Daraji and Salih (2012) who reported that carcass yield, and breast meat yield of broilers increased with increasing dietary inclusion of Arg. Jiao et al. (2010) also reported that Arg supplementation improved carcass yield of broilers. Corzo et al. (2003) also reported significant improvement in carcass yield, and reduction in abdominal fat of heavy broiler chickens fed diets containing increased level of Arg from 42 to 56 d. Fernandes et al. (2009) noted enhancement in breast weight and breast fillet weight of broilers fed diets supplemented with Arg. Improved dressing percentage obtained with turkeys fed diet supplemented with $1 \mathrm{~g} \mathrm{Arg} / \mathrm{kg}$ could be related to the functions of Arg, acting as substrate for biosynthesis of several molecules (such as protein, creatine, proline, ornithine, and polyamine), which are essential for growth, and tissue development (Chen et al., 2011). However, relative weights of retail cut parts were not affected in this study.

The development of lymphoid organ has been known to correlate directly with the health status of animals. Thymus and spleen weights are often times measured as indicators of health, and immunological stress (Kwak et al., 1999). The linear increase in thymus weights and quadratic increase in spleen weights obtained in the current study with increasing Arg supplementation corroborated the work of Munir et al. (2009) who reported that supplemental Arg enhanced thymus and spleen weights of broilers. Poor development of thymus and spleen has been associated with Arg deficiency (Kwak et al., 1999). Arginine supplementation was reported to improve thymus weight, function (Bristrain, 2004), and acted as a sensitive indicator of health, acute, and chronic stress responses (Shelat et al., 1997). Thymus weight is related to the magnitude of developing $\mathrm{T}$ cells, while spleen weight is related to the proliferation of immune cells within the secondary lymphoid tissue during periods of infection (Elmore, 2006; Pozo et al., 2009). 

organs. Abdukalykova and Ruiz-Feria (2006) demonstrated that high level of Arg accelerated antibody production in broiler chickens. Broilers fed diet supplemented with Arg and challenged with infectious bursal disease virus achieved higher thymus weight (Ruiz-Feria and Abdukalykova, 2009). Experimental models have also established the fact that Arg played an important role as a potent immunological modulator through production of nitric oxide, which has a direct influence on the immune system of birds (Friedman et al., 1998; Kidd et al., 2001).

\subsection{Gut microbiota}

Nutrition can be used to manipulate immune responsiveness to pathogens by providing substrate for immune cells or pathogens, protecting animal against immunopathology, influencing gut microbial populations, and the hormonal environment (Humphrey, 2004; Klasing, 2007). The gut microflora played a vital role in improving gut health of animals by protecting the host from oral pathogens (Ziegler et al., 2003). Greatest Lactobacillus count obtained in small intestinal content of turkeys fed the diet supplemented with $1 \mathrm{~g} / \mathrm{kg}$ of L-arg, and quadratic increase in cecal Lactobacillus counts as Arg supplementation increased from 0 to $1.0 \mathrm{~g} / \mathrm{kg}$ were indicative of improved gut health. Lactic acid bacteria happen to be the normal flora of gastrointestinal tract, which ferment carbohydrates or starch to produce lactic acid, and hydrogen peroxide as an end product (Harley and Prescott, 1993). Lactic acid reduced the $\mathrm{pH}$ of the gut, and thereby inhibited the growth of other bacteria including the enteropathogens; hence it had positive association with animal health (Rowland, 1992). The linear and quadratic increase in Clostridium and Coliform counts of the small intestinal content recorded with increasing dietary supplementation levels of Arg may not necessary suggest serious illness but 
may indicate the possible presence of other pathogenic organisms of faecal origin (Todar, 2007). High coliform count particularly E. coli species might be due to changes in gut profile to a population of coliform bacteria potentially beneficial to growth (Ravindran et al., 2006).

Quadratic reduction in Salmonella count obtained in the small intestinal content of $112 \mathrm{~d}$ turkeys as Arg supplementation increased from 0 to $1.0 \mathrm{~g} / \mathrm{kg}$ suggested a reduction effect on the concentration of Salmonella organisms following Arg supplementation. Eriksson et al. (2003) earlier noted that Arg supplementation reduced intestinal salmonella counts of poultry. The reduction effect of Arg on intestinal salmonella counts has been linked with nitric oxide produced following Arg supplementation. Nitric oxide has been described as a potent agent capable of limiting the growth of not only Salmonella Typhimurium but also that of other intracellular parasites (Eriksson et al., 2003). Identification of the Arg pathway which produces nitric oxide has led to the research demonstrating that macrophages produced by nitric oxide was increased by a local concentration of Arg, and could function as a defence mechanism against infection (Sung et al., 1991).

\section{Conclusion}

Arginine supplementation improved the haematology of finisher turkeys as indicated by increased PCV, improved serum chemistry of grower and finisher turkeys as indicated by increased total serum protein, and reduced serum enzymes with appreciable improvement obtained at $0.5 \mathrm{~g} \mathrm{Arg} / \mathrm{kg}$. Arginine supplementation further enhanced the relative weights of thymus, spleen, and reduced Salmonella counts in small intestine of finisher turkeys.

\section{Conflict of interest statement}


There is no conflict of interest with any individual or organization regarding the materials discussed in the manuscript.

\section{Acknowledgement}

The authors are grateful to the College of Animal Science and Livestock Production, and the World Bank Centre of Excellence in Agricultural Development and Sustainable Environment anchored in Federal University of Agriculture (Abeokuta, Nigeria) for sponsoring this project (Sponsor ID No: ACE. 023). Equipment subsidy grant from Alexander von Humboldt Foundation (Bonn, Germany) received by O.O. Oluwatosin (Grant No: 3.4-8151/15017) facilitated this work.

\section{References}

AOAC, 2000. Official method of Analysis of AOAC Int., 17th ed. Assoc. Off. Anal. Chem. Washington, DC., US.

Abdukalykova, S.T., Ruiz-Feria, C.A., 2006. Arginine and vitamin E improve the cellular and humoral immune response of broiler chickens. Int. J. Poult. Sci. 5, 121-127.

Al-Hassani, A.S., 2011. Effect of dietary supplementation with different levels of arginine on some blood traits of laying hens. Int. J. Poult. Sci. 10, 705-709.

Al-Daraji, H.J., Salih, A. M., 2012. The influence of dietary arginine supplementation on blood traits of broiler chickens. Pak. J. Nutri. 11, 258-264.

Allen, P.C., 1999. Effects of daily oral doses of L-arginine on coccidiosis infections in chickens. Poult. Sci. 78, 1506-1509. 
Atakisi, O., Atakisi, E., Kart, A. 2009. Effects of dietary zinc and L-arginine supplementation on total antioxidants capacity, lipid peroxidation, nitric oxide, egg weight and blood biochemical values in Japanese quails. Biol. Trace Elem. Res. 132, 136-143.

Bergmeyer, H.U., 1983. Methods of Enzymatic Analysis. Vol. III. Enzymes 1: Oxido-reductase, Transferase. Verlay Chemie, Deerfteld Beach, FL, pp. 126 - 510.

Bistrain, B.R., 2004. Practical recommendations for immune-enhancing diets. J. Nutr. 134, 28682872.

Bobek, S., Jastrzebski, M., Pietras, M., 1976. Age-related changes in oxygen consumption and plasma thyroid hormone concentration in the young chicken. Gen. Comp. Endocrinol. 31, 169-174.

Cannan, R. K., 1958. Book of Clinical Practical Chemistry. Vol. I, fifth ed. CBS Publisher, New Delhi, India. pp. 479-480.

Chen, J., Wang, M., Kong, Y., Ma, H., Zou, S., 2011. Comparison of the novel compounds creatine and pyruvate on lipid and protein metabolism in broiler chickens. J. Anim. Sci. 5, 1082-1089.

Corzo, A., Moran Jr, E.T., Hoehler, D., 2003. Arginine needs of heavy broiler males: Applying the ideal protein concept. Poult. Sci. 82, 402-407.

Davila, D.R., Brief, S., Simon, J., Hammer, R.E., Brinster, R.L., Kelley, K.W., 1987. Role of growth hormone in regulating $\mathrm{T}$ dependent immune events in aged, nude, and transgenic rodents. J. Neurosci. Res. 18, 108-116.

Dean, W., 1999. The neuroendocrine theory of aging part IV: The immune homeostat. Vit. Res. News. 13, 1-11. 
Deicher, R., Walter, H., 2005. Hormonal adjuvants for the treatment of renal anaemia. Eur. J. Clin. Invest. 35, 75-84.

Denli, M., Blandox, J.C., Guynot, M.E., Salado, S., Perez, J.F., 2009. Effects of dietary Afladetox on performance, serum biochemistry, histopathological changes, and aflatoxin residues in broilers exposed to aflatoxin B1. Poult. Sci. 88, 1444-1451.

Elmore, S.A., 2006. Enhanced histopathology of the thymus. Toxicol. Pathol. 34, 656-665.

Emadi, M., Kaveh, K., Bejo, M.H., Ideris, A., Jahanshiri, F., Ivan, M., Alimon, R.A., 2010. Growth performance and blood parameters as influenced by different levels of dietary arginine in broiler chickens. J. Anim. Vet. Adv. 9, 70-74.

Emadi, M., Jahanshiri, F., Kaveh, K., Hair-Bejo, M., Ideris, A., Alimon, A. R., 2011. Nutrition and immunity: the effects of the combination of arginine and tryptophan on growth performance, serum parameters and immune response in broiler chickens challenged with infectious bursal disease vaccine. Avian Pathol. 40, 63-72.

Eriksson, S., Chambers, B.J., Rhen, M., 2003. Nitric oxide produced by murine dendritic cells is cytotoxic for intracellular Salmonella enterica sv. Typhimurium. Scand. J. Immunol. 58, 493-502.

Ewuola, E.O., Ogunlade, J.T., Gbore, F.A., Egbunike, G.N., 2008. Serum biochemistry and organ traits of growing rabbits fed Fusarium verticilloides cultured maize-base diet. Proc. $33^{\text {rd }}$ Ann. Conf. NSAP, Ogun State, Nigeria, pp. 199-203.

Fernandes, J.I., Murakami, A.E., Martins, E.N., Sakamoto, M.I., Garcia, E.R., 2009. Effect of arginine on the development of the pectoralis muscle and the diameter and the protein: 
Deoxyribonucleic acid rate of its skeletal myofibers in broilers. Poult. Sci. 88, 13991406.

Friedman, A., Bartov, I., Sklan, D., 1998. Humoral immune response impairment following excess vitamin E nutrition in the chick and turkey. Poult. Sci. 77, 956-962.

Grunwaldt, E.G., Guevara, J.C., Estevez, O.R., Vicente, A., Rousselle, H., Alcunten, N., Aguerregaray, D., Stasi, C.R., 2005. Biochemical and haematological measurements in beef cattle in Mendoza plain rangelands (Agerntina). Trop. Anim. Health Prod. 37, $527-540$.

Harley, J. P., Prescott, L. M., 1993. Laboratory Exercises in Microbiology. 2nd edition. W.M.C. Brown Publishers, New York, US.

Humphrey, B.D., Klasing, K.C., 2004. Modulation of nutrient metabolism and homeostasis by the immune system. World's Poult. Sci. J. 60, 90-100.

Jensen, J.F., 1984. Method of dissection of broiler carcasses and description of parts. Papworth's Pandragon Press. Cambridge, UK. pp. 32-61.

Jiao, P., Guo, Y., Yang, X., Long, F., 2010. Effects of dietary arginine and methionine levels on broiler carcass traits and meat quality. J. Anim. Vet. Adv. 9, 1546-1551.

Khajali, F., Wideman, R. F., 2010. Dietary arginine: Metabolic, environmental, immunological and physiological interrelationships. World's Poult. Sci. J. 66, 751-766.

Khajali, F., Tahmasebi, M., Hassanpour, H., Akbari, M.R., Qujeq, D., Wideman, R.F., 2011. Effects of supplementation of canola meal-based diets with arginine on performance, plasma nitric oxide and carcass characteristics of broiler chickens grown at high altitude. Poult. Sci. 90, 2287-2294. 
Kidd, M.T., Peebles, E.D., Whitmarsh, S.K., Yeatman, J.B., Wideman Jr, R.F., 2001. Growth and immunity of broiler chicks as affected by dietary arginine. Poult. Sci. 80, 1535-1542.

Klandorf, H., Sharp, P.J., Newcomer, W.S., 1981. The influence of feeding patterns on daily variation in the concentrations of plasma thyroid hormones in the hen. IRC Med. Sci. 9, 82-87.

Klasing, K.C., 2007. Nutrition and the immune system. Br. Poult. Sci. 48, 525-537.

Kozdag, G., Ural, D., Vural, A., Agacdiken, A., Kahraman, G., Sahin, T., Ural, E., Komsuoglu, B., 2005. Relation between free triiodothyronine/free thyroxine ratio, echocardiographic parameters and mortality in dilated cardiomyopathy, Eur. J. Heart Failure 7, 113-118

Kozwich, D., Johansen, K.A., Landau, K., Roehl, C.A., Woronoff, S., Roehl, P.A., 2000. Development of a novel, rapid integrated cryptosporidium parvum detection assay. Appl. Environ. Microbiol. 66, 2711-2717.

Kwak, H., Austic, R.E., Dietert, R.R., 1999. Influence of dietary arginine concentration on lymphoid organ growth in chickens. Poult. Sci. 78, 1536-1541.

Le Roith, D., Bondy, C., Yakar, S., Liu, J., Butler, A., 2001. The somatomedin hypothesis. Endocrin. Rev. 22, 53-74.

Li, P., Yin, Y.L., Li, D., Kim, S.W., Wu, G. 2007. Amino acids and immune function. Br. J. Nutr. 98, 237-252.

Liu, X., Wu, X., Yin, Y., Liu, Y., Geng, M., Yang, H., Wu, G., 2012. Effects of dietary Larginine or $\mathrm{N}$-carbamylglutamate supplementation during late gestation of sows on the miR-15b/16, miR-221/222,VEGFA and eNOSexpression in umbilicalvein. Amino Acids 42, 2111-2119. 
Maroufyan, E., Kasim, A., Hashemi, S.R., Loh, T.C., Bejo, M.H., 2010. Responses of performance and differential leukocyte count to methionine and threonine supplementations on broiler chickens challenged with infectious bursal disease in tropical condition. Asian J. Biol. Sci. 3, 68-76.

Montali, R. J., 1988. Comparative pathology of inflammation in the higher vertebrates (reptiles, birds and mammals). J. Comp. Pathol. 99, 1-26

Munir, K., Muneer, M.A., Masaoud, E., Tiwari, A., Mahmud, A., Chaudhry, R.M., 2009. Dietary arginine stimulates humoral and cell-mediated immunity in chickens vaccinated and challenged against hydropericardium syndrome virus. Poult. Sci. 88, 1629 -1638.

NRC, 1994. Nutrient Requirements of Poultry 9th ed. Natl. Acad. Press, Washington, D.C., US. Oduguwa, O.O., Ogunmodede, B.K., 1995. Comparative growth response of three commercial vitamins and trace minerals premixes for rearing broiler chicks at the starter and finisher phases. Pertanika J. Trop. Agric. 19, 81-87.

Pozo, A.L., Godfrey, E.M., Bowles, K.M., 2009. Splenomegaly: investigation, diagnosis and management. Blood Rev. 23, 105-111.

Ravindran, V., Morel, P. C., Partridge, G.G., Hruby, M., Sands, J.S., 2006. Influence of an Escherichia coli-derived phytase on nutrient utilization in broiler starters fed diets containing varying concentrations of phytic acid. Poult. Sci. 85, 82-89.

Ren, W.K., Luo, W., Wu, M.M., Liu, G., Yu, X., Fang, J., Li, T., Yin, Y., Wu, G., 2013. Dietary L- glutamine supplementation improves pregnancy outcome in mice infected with type-2 porcine circovirus. Amino Acids 45, 479-488.

Ren, W., Yin, J., Wu, M., Liu, G., Yang, G., Xion, Y., Su, D., Wu, L., Li, T., Chen, S., Duan, J., Yin, Y., Wu, G., 2014. Serum amino acids profile and the beneficial effects of L- 
arginine or L- glutamine supplementation in Dextran sulfate sodium colitis. PLoS One 9, e88335.

Ren, W., Yin, Y., Liu, G., Yu, X., Li, Y., Yang, G., Li, T., Wu, G., 2012. Effect of dietary arginine supplementation on reproductive performance of mice with porcine circovirus type 2 (PCV2) infection". Amino Acids 42, 2089-2094

Rosa, C. A., Miazzo, R., Magnoli, C., Salvano, M., Chriac, S. M., Ferrero, S., 2001. Evaluation of the efficiacy of bentonite from the South Argentina to ameliorate the toxic effects of aflatoxin in broilers, Poult. Sci. 80, 139-144.

Rowland, R., 1992. Metabolic interactions in the gut. In: R. Fuller, ed. Probiotics: The Scientific Basis, Chapman and Hall, New York, US.

Ruiz-Feria, C.A., Abdukalykova, S. T., 2009. Arginine and vitamin E improve the antibody response to Infectious Bursal Disease Virus (IBDV) and sheep red blood cells in broiler chickens. Br. Poult. Sci. 50, 291-297.

SAS, 1999. SAS/STAT User's Guide SAS Inst. Inc., Cary, NC, US.

Schalm, O.W., Jain, N.C., Qureshi, M.Q., 1975. Veterinary Hematology, third ed. Lea and Fibinger, Philadilphia, PA, US.

Shelat, S.G., Arid, F., Redei, E., 1997. Exposure to dehydroepiandrosterone in utero affect Tcell function in males only. Neuro-immunomodulation 4, 154-162.

Stechmiller, J.K., Langkamp-Henken, B., Childress, B., Herrlinger-Garcia, K.A., Hudgens, B., Tian, J., 2005. Arginine supplementation does not enhance serum nitric oxide levels in elderly nursing home residents with pressure ulcers. Biol. Res. Nursing 6, 289-299 
Sung, Y.J., Hotchkiss, J.H., Austic, R.E., Dietert, R.R., 1991. L- arginine dependent production of a reactive nitrogen intermediate by macrophages of a uricotelic species. J. Leukocyte Biol. 50, 49-56

Swaggerty, C.L., Pevzner, I.Y., Lowry, V.K., Farnell, M.B., Kogut, M.H., 2003. Functional comparison of heterophils isolated from commercial broiler chickens. Avian Pathol. 32, 95-102.

Szabo, A., Mezes, M., Horn, P., Suto, Z., Bazar, G., Ramvari, R., 2005. Developmental dynamics of some blood biochemical parameters in the growing turkey (Meleagaris gallopavo). Acta Vet. Hungary, 53, 397-409.

Tan, B., Yin, Y., Liu, Z., Li, X., Xu, H., Kong, X., Huang, R., Tang, W., Shinzato, I., Smith, S., Wu, G., 2009. Dietary L- arginine supplementation increases muscle gain and reduces body fat mass in growing-finishing pigs. Amino Acids 37, 169-175

Tan, B.E., Yin, Y.L., Liu, Z.Q., Tang, W.J., Xu, H.J., Konga, X.F., Li, X.G., Yao, K., Gu, W.T., Smith, S.B., Wu, G.Y., 2011. Dietary L- arginine supplementation differentially regulates expression of fat-metabolic genes in porcine adipose tissue and skeletal muscle. J. Nutr. Bioc. 22, 441-445.

Tan, B.E., Yin, Y.L., Liu, Z.Q., Tang, W.J., Xu, H.J., Konga, X.F., Li, X.G., Yao, K., Gu, W.T., Smith, S.B., Wu, G.Y., 2011. Dietary L- arginine supplementation differentially regulates expression of fat-metabolic genes in porcine adipose tissue and skeletal muscle. J. Nutr. Bioc. 22, 441-445.

Todar, K., 2007. "Pathogenic Escherichia. coli". Online Textbook of Bacteriology. University of Wisconsin-Madison, Department of Bacteriology. Retrieved 2015-11-30. 
Tayade, C., Koti, M., Mishra, S.C., 2006. L- arginine stimulates intestinal intraepithelial lymphocyte functions and immune response in chickens orally immunized with live intermediate plus strain of infectious bursal disease vaccine. Vaccine 24, 5473-5480.

Uni, Z., Ferket, P., 2003. Enhancement of development of oviparous species by in ovo feeding. U.S. Regular Patent US 6,592,878 B2, Washington, DC., US.

Varley, H., Gowenlock, A. H., Bell, M., 1980.The Plasma Proteins. In: Practical Clinical Biochemistry, Vol. I5th edition. William Heinemann Medical Books Ltd, London. pp. $535-595$.

Westenfelder, C. 2002. Unexpected renal actions of erythropoietin. Experim. Nephrol. 10, 294298.

Wootton, I.D.P., 1964. Micro-analysis in Medical Biochemistry, 4th ed. J. and A. Churchill, London, UK. pp. $86-95$.

Wu, G., 2009. Amino acids: metabolism, functions, and nutrition. Amino acids. 37, 1-17.

Wu, L.Y., Fang, Y.J., Guo, X.Y., 2011. Dietary L- arginine supplementation beneficially regulates body fat deposition of meat-type ducks. Br. Poult. Sci. 52, 221-226.

Wu, X., Wu, Y.L., Yin, Y.Q., Liu, X.D., Liu, Z.Q., Liu, T.J., Li, R., Huang, L., Ruan, Z., Deng Z., 2012. Effect of dietary arginine and N-carbamoylglutamate supplementation reproduction and gene expression of eNOS, VEGFA and PlGF1 in on in late pregnancy of sows placenta. Anim. Reprod. Sci. 132, 187-192

Xia, M.S., Hu, C.H., Xu, Z.R., 2004. Effect of copper-bearing montmorillonite on growth performance, digestive enzyme activities, and intestinal microflora and morphology of male broiler. Poult. Sci. 83, 1868-1875. 
582

583

584

585

586

587

588

589
Yin, J., Ren, W., Duan, J., Wu, L., Chen, S., Li, T., Yin, Y., Wu, G. 2014. Dietary arginine supplementation enhances intestinal expression of SLC7A7 and SLC7A1 and ameliorates growth depression in mycotoxin-challenged pigs. Amino Acids 46, 883-892.

Ziegler, T.R., Evans, M.E., Fernandez-Estivariz, C., Jones, D. P., 2003. Trophic and cytoprotective nutrition for intestinal adaptation, mucosal repair, and barrier function. Annu. Rev. Nutr. 23, 229-261. 
Table 1

591 Composition of basal diet for grower (d 56 to 84) and finisher (d 84 to 112) turkeys ${ }^{\mathrm{a}}$

\begin{tabular}{lll}
\hline Item & Grower & Finisher \\
\hline Ingredient (g/kg) & & \\
Maize & 575 & 622 \\
Fish meal $(720 \mathrm{~g} / \mathrm{kg})$ & 89 & 46 \\
Soybean meal & 264 & 240 \\
Soybean oil & - & 2 \\
Wheat offal & 47 & 65 \\
Bone meal & 6 & 6 \\
Limestone & 8 & 8 \\
Vitamin/mineral premix & 5 & 5 \\
L-Lys & 1 & 1 \\
DL-Met & 2 & 2 \\
Salt & 3 & 3 \\
Total & 1,000 & 1,000 \\
Calculated composition & & \\
Ca (g/kg) & 10.5 & 9.5 \\
P (g/kg) & 6.5 & 5.4 \\
Metabolizable energy & 3,196 & 3,275 \\
(kcal/kg) & & \\
Determined composition (g/kg DM basis) & \\
Crude protein & 230.3 & 195.5 \\
Crude fiber & 33.2 & 39.0 \\
Ether extract & 32.1 & 30.7 \\
Indispensable amino acids & & \\
Arg & 16.3 & 14.3 \\
His & 6.6 & 5.9 \\
Ile & 11.0 & 9.3 \\
Leu & 21.6 & 20.0 \\
Lys & 14.3 & 11.3 \\
Met & 5.5 & 4.6 \\
Phe & 11.7 & 10.5 \\
Thr & 11.5 & 8.1 \\
Val & 12.4 & 10.3 \\
Dispensable amino acids & & \\
Asp & 24.8 & 21.4 \\
Cys & 36.0 & 33.0 \\
Glu & 43.4 & 39.9 \\
Gly & 11.2 & 9.4 \\
Ala & 13.7 & 11.9 \\
Pro & 14.0 \\
Ser & & 10.3 \\
Tyr & 4.8 \\
\hline
\end{tabular}


aProvided vitamin-mineral premix per kilogram of diet: 1,200 IU vitamin A; $300 \mathrm{IU}$ vitamin $\mathrm{D}_{3} ; 4.2 \mathrm{mg}$ vitamin $\mathrm{E} ; 0.2 \mathrm{mg}$ vitamin $\mathrm{K}_{3} ; 0.2 \mathrm{mg}$ vitamin $\mathrm{B}_{1} ; 0.66 \mathrm{mg}$ vitamin $\mathrm{B}_{3} ; 0.5$ $\mathrm{mg}$ vitamin $\mathrm{B}_{6} ; 2 \mu \mathrm{g}$ vitamin $\mathrm{B}_{12} ; 0.1 \mathrm{mg}$ folic acid; $0.02 \mathrm{mg}$ biotin; $1.5 \mathrm{mg}$ Ca pantothenate, $0.07 \mathrm{~g}$ choline chloride; $12 \mathrm{mg}$ antioxidant (butylhydroxytoluene); $0.23 \mathrm{~g} \mathrm{Ca} ; 0.5 \mathrm{mg} \mathrm{Cu} ; 5.1 \mathrm{mg}$ $\mathrm{Zn} ; 6 \mathrm{mg} \mathrm{Fe} ; 7.1 \mathrm{mg} \mathrm{Mn} ; 0.06 \mathrm{mg} \mathrm{I}$; and $0.02 \mathrm{mg} \mathrm{Se}$. 


\section{Table 2}

Effect of Arg supplementation on haematological indices of grower (d 56 to 84) and finisher (d 84 to 112$)$ turkeys $^{\mathrm{a}}$

\begin{tabular}{|c|c|c|c|c|c|c|}
\hline \multirow[t]{2}{*}{ Item } & \multicolumn{3}{|l|}{$\operatorname{Arg}(g / k g)$} & \multirow{2}{*}{$\begin{array}{l}\text { Pooled } \\
\text { SEM }\end{array}$} & \multicolumn{2}{|c|}{$P$-value } \\
\hline & 0 & 0.5 & 1.0 & & Linear & Ouadratic \\
\hline \multicolumn{7}{|l|}{ d 84} \\
\hline Packed cell volume (\%) & 35.33 & 35.83 & 36.33 & 1.64 & 0.555 & 0.190 \\
\hline Hemoglobin $(\mathrm{g} / \mathrm{dL})$ & 11.57 & 11.77 & 12.22 & 0.54 & 0.468 & 0.429 \\
\hline Red blood cell $\left(\times 10^{12} / \mathrm{L}\right)$ & 2.33 & 2.34 & 2.40 & 0.05 & 0.609 & 0.790 \\
\hline White blood cell $\left(\times 10^{9} / \mathrm{L}\right.$ & 8.13 & 11.22 & 15.32 & 1.51 & 0.254 & 0.107 \\
\hline Heterophil (\%) & 36.2 & 39.5 & 43.5 & 1.9 & 0.403 & 0.205 \\
\hline Lymphocyte (\%) & 55.0 & 60.5 & 56.0 & 2.6 & 0.797 & 0.152 \\
\hline Eosinophil (\%) & 3.5 & 3.5 & 2.7 & 0.5 & 0.017 & 0.142 \\
\hline Basophil (\%) & 0 & 0 & 0 & 0 & - & - \\
\hline Monocyte (\%) & 0.5 & 0.5 & 0.0 & 0.1 & 0.072 & 0.281 \\
\hline \multicolumn{7}{|l|}{ d 112} \\
\hline Packed cell volume (\%) & 29.17 & 33.17 & 33.00 & 5.69 & 0.019 & 0.017 \\
\hline Hemoglobin $(\mathrm{g} / \mathrm{dL})$ & 9.97 & 10.60 & 9.89 & 0.17 & 0.908 & 0.097 \\
\hline Red blood cell $\left(\times 10^{12} / \mathrm{L}\right)$ & 1.95 & 2.77 & 1.85 & 0.12 & 0.751 & $<0.001$ \\
\hline White blood cell $\left(\times 10^{9} / \mathrm{L}\right)$ & 13.03 & 11.25 & 12.41 & 2.25 & 0.319 & 0.004 \\
\hline Heterophil (\%) & 32.50 & 23.67 & 27.50 & 3.98 & 0.032 & $<0.001$ \\
\hline Lymphocyte (\%) & 65.7 & 72.5 & 70.5 & 9.8 & 0.011 & $<0.001$ \\
\hline Eosinophil (\%) & 0 & 0.3 & 0 & 0.1 & 0.070 & 0.116 \\
\hline Basophil (\%) & 0.5 & 2.5 & 1.0 & 0.3 & 0.441 & $<0.001$ \\
\hline Monocyte (\%) & 0.5 & 0.0 & 1.5 & 0.2 & 0.019 & $<0.001$ \\
\hline
\end{tabular}

601

${ }^{\mathrm{a}}$ Based on 6 pens/treatment; and SEM = standard error of the mean.

602

603

604

605

606

607

608

609

610 
612 Effect of Arg supplementation on serum chemistry of grower (d 56 to 84) and finisher (d 84 to 613 112) turkeys

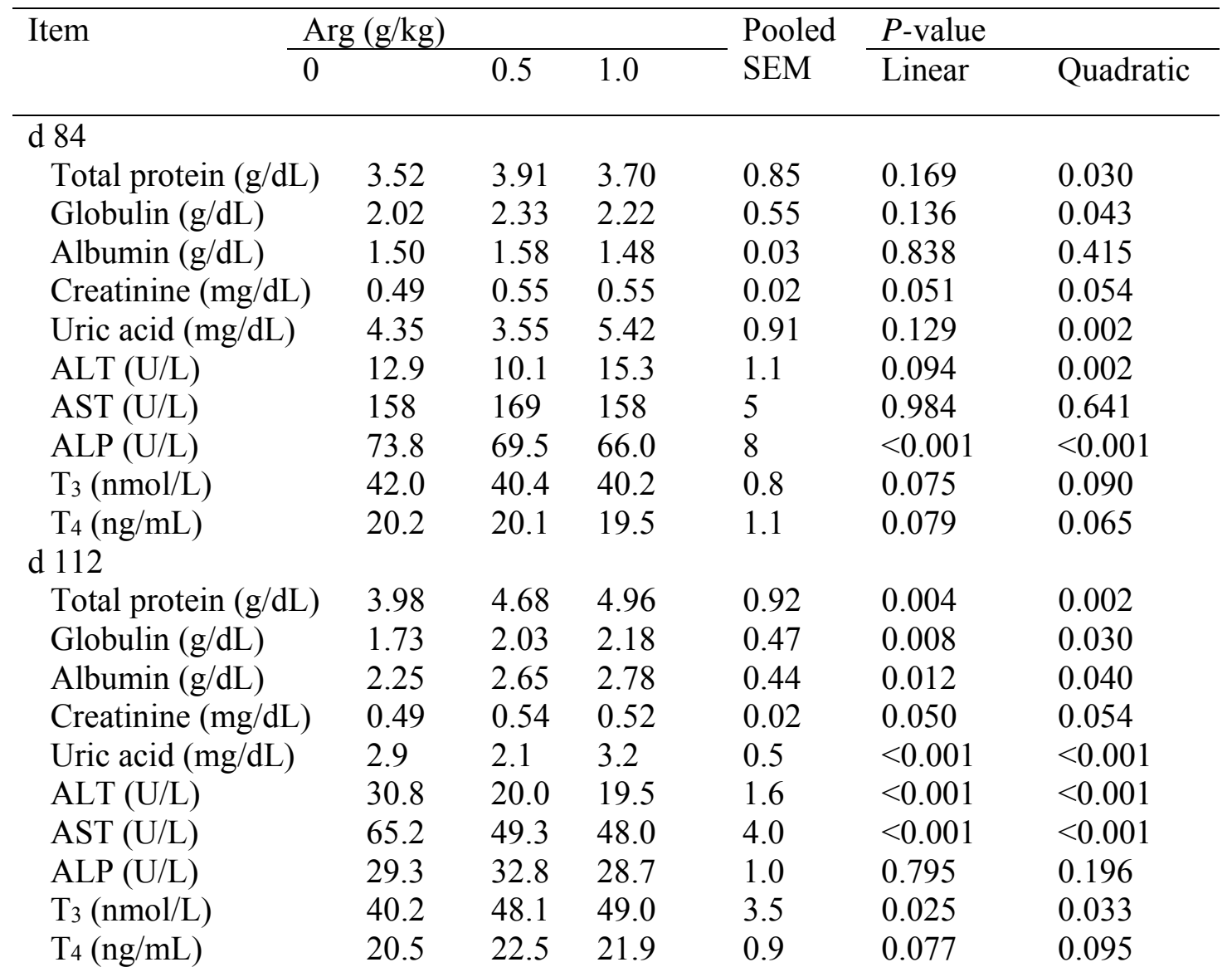

${ }^{\mathrm{a}}$ Based on 6 pens/treatment, SEM = pooled standard error of means, $\mathrm{PCV}=$ packed cell volume, $\mathrm{RBC}=$ red blood cell, $\mathrm{WBC}=$ white blood cell, $\mathrm{ALT}=$ alanine amino transferase, $\mathrm{AST}=$ aspartate amino transferase, $\mathrm{ALP}=$ alkaline phosphate, $\mathrm{T}_{3}=$ triodosterine, and $\mathrm{T}_{4}=$ total thyroxine. 
619 Effect of Arg supplementation on carcass yield and relative organ weights of turkeys ${ }^{\mathrm{a}}$

\begin{tabular}{|c|c|c|c|c|c|c|}
\hline \multirow[t]{2}{*}{ Item } & \multicolumn{3}{|c|}{$\operatorname{Arg}(\mathrm{g} / \mathrm{kg})$} & \multirow{2}{*}{$\begin{array}{l}\text { Pooled } \\
\text { SEM }\end{array}$} & \multicolumn{2}{|l|}{$P$-value } \\
\hline & 0 & 0.5 & 1.0 & & Linear & Quadratic \\
\hline Body weight (g/bird) & 9,027 & 8,660 & 9,480 & 164 & 0.125 & 0.040 \\
\hline Defeathered weight (g/bird) & 8,167 & 7,833 & 8,867 & 158 & 0.062 & 0.020 \\
\hline Dressing percentage $(\%)$ & 75.92 & 74.67 & 79.70 & 7.98 & 0.042 & 0.022 \\
\hline \multicolumn{7}{|l|}{$\begin{array}{l}\text { Retail cut parts } \\
\text { (percentage body weight) }\end{array}$} \\
\hline Shank & 3.99 & 4.01 & 3.63 & 0.34 & 0.709 & 0.805 \\
\hline Breast & 26.56 & 26.71 & 27.15 & 0.42 & 0.626 & 0.889 \\
\hline Thigh & 9.50 & 9.51 & 10.28 & 0.65 & 0.072 & 0.104 \\
\hline Drum stick & 10.32 & 9.27 & 9.97 & 0.38 & 0.738 & 0.348 \\
\hline Back & 15.11 & 10.78 & 16.42 & 1.20 & 0.603 & 0.053 \\
\hline Wings & 11.1 & 10.7 & 10.0 & 0.5 & 0.055 & 0.060 \\
\hline \multicolumn{7}{|l|}{$\begin{array}{l}\text { Organs and offals } \\
\text { (percentage body weight) }\end{array}$} \\
\hline Liver & 1.14 & 1.26 & 1.07 & 0.04 & 0.482 & 0.098 \\
\hline Kidney & 0.43 & 0.43 & 0.44 & 0.01 & 0.669 & 0.804 \\
\hline Lungs & 0.55 & 0.45 & 0.33 & 0.09 & 0.007 & 0.882 \\
\hline Whole gizzard & 2.33 & 2.22 & 2.15 & 0.07 & 0.341 & 0.902 \\
\hline Empty gizzard & 1.60 & 1.56 & 1.52 & 0.05 & 0.559 & 0.984 \\
\hline Proventriculus & 0.17 & 0.14 & 0.13 & 0.01 & 0.062 & 0.409 \\
\hline Pancreas & 0.13 & 0.12 & 0.11 & 0.01 & 0.085 & 0.584 \\
\hline Bursa & 0.05 & 0.06 & 0.04 & 0.01 & 0.284 & 0.146 \\
\hline Spleen & 0.05 & 0.07 & 0.08 & 0.01 & 0.006 & 0.131 \\
\hline Gastrointestinal weight & 2.96 & 2.97 & 2.67 & 0.12 & 0.380 & 0.605 \\
\hline Crop & 0.68 & 0.62 & 0.36 & 0.09 & 0.202 & 0.622 \\
\hline Thymus & 0.03 & 0.06 & 0.06 & 0.01 & 0.791 & 0.030 \\
\hline Heart & 0.42 & 0.34 & 0.43 & 0.02 & 0.884 & 0.003 \\
\hline
\end{tabular}


629 Effect of Arg supplementation on gut microflora ( $\log 10 \mathrm{cfu}$ microorganism $/ \mathrm{g})$ in turkeys ${ }^{\mathrm{a}}$

\begin{tabular}{lllllll}
\hline Item & \multicolumn{3}{l}{$\operatorname{Arg}(\mathrm{g} / \mathrm{kg})$} & Pooled & \multicolumn{2}{l}{$P$-value } \\
\cline { 2 - 3 } & 0 & 0.5 & 1.0 & SEM & Linear & Quadratic \\
\hline Small intestine & & & & & & \\
$\quad$ Clostridium & 5.6 & 6.2 & 6.3 & 1.0 & $<0.001$ & $<0.001$ \\
Coliform & 5.4 & 5.8 & 6.0 & 0.9 & $<0.001$ & $<0.001$ \\
Lactobacillus & 5.2 & 5.0 & 5.6 & 1.0 & 0.092 & 0.002 \\
$\quad$ Salmonella & 5.6 & 5.1 & 5.0 & 1.0 & 0.060 & 0.029 \\
Caecum & & & & & & \\
$\quad$ Clostridium & 7.6 & 7.5 & 7.7 & 0.1 & 0.085 & 0.090 \\
Coliform & 6.9 & 6.9 & 6.6 & 0.1 & 0.077 & 0.095 \\
Lactobacillus & 6.4 & 6.9 & 6.9 & 1.0 & 0.066 & 0.030 \\
$\quad$ Salmonella & 6.2 & 6.4 & 6.0 & 0.1 & 0.072 & 0.065 \\
\hline
\end{tabular}

631

632

633

634

635

636

637

638

639 